\title{
H.A.R.O.T. Human assisted reproduction ozone therapy: the use of Oxygen-Ozone therapy as an adjunct in the therapy of couple sterility
}

\author{
Alfonso Maria Irollo, ${ }^{1}$ Maria Francesca Gangale, ${ }^{2}$ Gennaro Calabrese, ${ }^{3}$ Ezio Stortini, ${ }^{1}$ Sara Zanconi, ${ }^{4}$ \\ Raffaele Aiello, ${ }^{1}$ Catella Criscuolo, ${ }^{2}$ Vincenzo Infante, ${ }^{2}$ Antonella Tartaglione, ${ }^{1}$ Simona Pizzinelli, ${ }^{1}$ \\ Maria Laura De Simone ${ }^{3}$
}

${ }^{1}$ Clinica Chianciano Salute, Chianciano Terme (SI); ${ }^{2}$ Omia Salute, Roma; ${ }^{3}$ Centro Omnia Salute Gragnano, Gragnano (NA); ${ }^{4}$ O.P. Santa Lucia, Macerata, Italy

\begin{abstract}
The increase in couple sterility and the average increase in the age of women seeking pregnancy has placed the scientific community in front of the need to improve the quality of oocytes and the percentage of the embryonic implantation. The oxygen- ozone therapy seems to be able to help in this research thanks to its modes of action. A therapeutic protocol, identified with the acronym H.A.R.O.T (Human assisted reproduction ozone therapy) has been developed, the first results of which seem to be considerably encouraging in order to obtain a greater number and quality of oocytes and improve the percentage of embryonic implantation.
\end{abstract}

\section{Introduction}

Sterility is commonly defined as the absence of conception after 12 months of unprotected sexual intercourse.

With the term infertility we mean said absence in couples who already procreated.

However, this definition should not be intended absolutely, in fact in the definition of sterile couple to be initiated to the diag-

\footnotetext{
Correspondence: Alfonso Maria Irollo, Clinica Chianciano Salute, via C. Marchesi 73, Chianciano Terme (SI), Italy.

E-mail: agoi@me.com
}

Key words: Oxygen-ozone therapy; oocytes quality; embryonic transfer; ovulation induction; HAROT.

Received for publication: 19 November 2019.

Accepted for publication: 19 November 2019.

${ }^{\circ}$ Copyright: the Author(s), 2019

Licensee PAGEPress, Italy

Ozone Therapy 2019; 4:8700

doi:10.4081/ozone.2019.8700

This article is distributed under the terms of the Creative Commons Attribution Noncommercial License (by-nc 4.0) which permits any noncommercial use, distribution, and reproduction in any medium, provided the original author(s) and source are credited. nostic-therapeutic process also intervene important factors, such as for example: age, abnormal lifestyle, medical history that may induce to anticipate or delay the therapeutic approach.

The oxygen-ozone therapy is a therapeutic procedure that uses a mixture of gases: oxygen and ozone.

Its first use dates back to 1915, then it has been studied and tested all over the world. In Italy its official use dates back to 1983.

Scientific studies show that this is the therapeutic method with less risks of side effects (Jacobs 1981, 0.0007\% side effects). The only side effects are cough in case of accidental inhalation and hypotension in case of bad practice.

Precautions for safe operation: i) right administration route; ii) use of proper equipment; iii) use by experienced physicians, qualified by the Società Scientifica di Ossigeno-Ozono Terapia (SIOOT); iv) no inhalation.

The only contraindications are: i) hyperthyroidism; ii) favism; iii) pregnancy in progress;

Administration routes are multiple and depend on the indication, we distinguish between: i) big blood auto-infusion intravenously; ii) anal insufflation; iii) vaginal-uterotubal insufflation; iv) small blood infusion intramuscularly.

Couple sterility is a continuously increasing disease; today more and more couples address to in vitro fertilization (IVF) techniques to solve their problem.

ISTAT (Italian National Statistics Institute) data show that about $35 \%$ of couples are affected by this disease; the numbers are constantly increasing so as to define this pathology as a real social disease.

The causes of this increase are to be found in the increasingly advanced age of women in search of their first child, in the environmental pollution factors that affect the quality of human gametes, and the presence of some individuals who in the past did not reach the age to procreate due to diseases that today can instead be solved thanks to the progress of medicine.

Since July 25, 1978, when Louise Brown was born thanks to the first IVF performed by Robert Edwards, so much progress has been made in the execution of these methods.

The two key points of this method that are capable of positively influencing the outcome are the quality of the oocytes, and the understanding and improvement of embryonic implantation, as arises from the most recent congresses and debates between operators. ${ }^{1-53}$

\section{Object}

The study object is to demonstrate how the oxygen-ozone therapy applied to IVF can help the treatment by positively influ- 
encing the quality of oocytes and the mechanisms of embryonic implantation.

\section{Rationale}

The study rationale is based on the effects of oxygen-ozone therapy, validated by the consensus of the scientific community (Viebahn, 1994; Richelmi et al., 2001; Fabris, 2009), on some functions and processes of the organism, as follows: i) anti-inflammatory activity: reduction of TNF-alpha levels; ii) anti-oxidant activity: it activates anti-oxidant enzymes (catalase, superoxide dismutase, glutathione), particularly at mitochondrial level, free radicals' reduction; iii) neoangiogenesis induction: improvement and reactivation of blood circulation and microcirculation; iv) rising of $\mathrm{O}_{2}$ release in tissues by haemoglobin, by rising 2,3DPG (diphosphoglycerate) production, rising of red blood cells deformability while improving their pass inside small capillaries, viscosity reduction; v) dysbiosis normalizing activity; vi) rising of energy production (ATP) by accelerating fat acids catabolism, glycolysis acceleration; vii) immunomodulatory activity, by acting on lymphocytes and monocytes, lowering of circulating immunocomplexes in autoimmune diseases; viii) it improves the functionality of emune organs, by promoting the elimination of metals and toxic substances.

But also disclosing the modes of action with which the oxygen therapy could improve the embryonic implantation and the quality of the oocytes, as follows: i) improvement of subendometrial microcirculation; ii) release of growth factors with triggering of tissue regeneration mechanisms; iii) improvement of tissue oxygenation; iv) reduction of TNF- $\alpha$ and increase of interleukin $10 ; \mathrm{v}$ ) endometrial inflammation reduction; vi) improvement of the vaginal uterine and intestinal microbiota; vii) improvement of perifollicular microcirculation; viii) release of growth factors with triggering of regeneration mechanisms; ix) reduction of free radicals' concentration in the follicular fluid; $\mathrm{x}$ ) better $\mathrm{O}_{2}$ concentration in the follicular fluid; xi) increased activity of oocyte mitochondria; xii) slowing down the reduction of telomere bases; xiii) reduction of heavy metals concentration in the follicular fluid; xiv) reduction of biogenic amines by promoting the elimination of dysbiosis.

\section{Materials and Methods}

In order to demonstrate the object of said study, we recruited: i) 500 couples with primary sterility; ii) 100 couples owning 2 vitrified embryos.

The 500 couples were divided into 2 homogeneous groups taking into account the age and the cause of sterility

\section{Group A and Group B}

It should be noted that in order to make the division more homogeneous in the two groups, 150 couples of group B are the same who performed the same procedure a few months earlier; these couples have been identified as subgroups B1 and A1.

The age of the recruited women was between 30 and 46 years. Only couples affected by the following causes were considered:

pathological semen (sperm count between 1,000,000 and $7,000,000$ sperm cells), tubal pathology or bilateral imperviousness and $3^{\text {rd }}$ degree endometriosis.

The 100 couples with at least 2 vitrified embryos were also divided into two groups - Group C and Group D. In dividing the couples, the age of the patients, the quality of the vitrified embryos and the stage of evolution (embryos in $3^{\text {rd }}$ day and blastocysts) were taken into account.
Women belonging to the group of 500 couples have all been subjected to: i) diagnostic hysteroscopy to assess the uterine cavity; ii) stimulation protocols with follitropin alpha 300 IU per day for women under the age of 35 and Menotropin $300 \mathrm{IU}$ for women over the age of 35 and for women with endometriosis; iii) posttransfer supplementation therapy with progesterone $100 \mathrm{mg}$, acetylsalicylic acid $100 \mathrm{mg}$ and prednisone $5 \mathrm{mg}$ and Nadroparin Calcium 2850 IU.

The women of group B underwent 3 LBI (large blood infusion): i) before ovarian stimulation (about one week); ii) in the middle of the stimulation (follicles between 12 and $14 \mathrm{~mm}$ ); iii) at embryo transfer.

Women belonging to the group of 100 couples with vitrified embryos have all been subjected to: i) diagnostic hysteroscopy to assess the uterine cavity; ii) endometrium preparation with estradiol valerate $8 \mathrm{mg}$ /day associated to progesterone $100 \mathrm{mg}$, when the proliferative endometrium exceeded $8 \mathrm{~mm}$ in thickness; iii) posttransfer supplementation therapy with progesterone $100 \mathrm{mg}$, acetylsalicylic acid $100 \mathrm{mg}$ and prednisone $5 \mathrm{mg}$ and Nadroparin Calcium 2850 IU.

The women of group D underwent 3 LBI (large blood infusion): i) a few days before the start of endometrial preparation; ii) associated with progesterone ( $24 \mathrm{~h}$ before or after); iii) at transfer.

The parameters used to highlight the differences between group A and B induced by oxygen-ozone therapy are the following: i) dosage of $17 \beta$-estradiol on the day of induction; ii) number of mature follicles; iii) number of oocytes; iv) oocytes quality; v) fertilization index; vi) $\mathrm{sO}_{2}, \mathrm{pO}_{2}$; vii) number of embryos; viii) embryos quality; ix) embryonic implantation percentage.

The parameters used to highlight the differences between group $\mathrm{C}$ and $\mathrm{D}$ induced by oxygen-ozone therapy are the following: i) endometrial size at the time of association with progestin and transfer; ii) $\mathrm{sO}_{2}$ and $\mathrm{pO}_{2}$ values at transfer; iii) implantation percentage.

In order to carry out this study, we used the IVF Chianciano Salute laboratory and the TOMA SUD clinical analysis laboratory. We used the following instruments: i) MEDICAL99IR Portable Unit for Oxygen Ozone Therapy by Multiossigen; ii) blood POC analyzer by i-STAT Abbot; iii) Samsung A30 and Samsung mysono U6 ultrasound machine.

\section{Results}

The results of the IVF techniques of couples A and B and of the transfers of couples of group C and D are shown in Tables 1 and 2.

Table 1. The parameters used Group B.

Evaluated parameters Group B

Dosage of 17 beta-estradiol on the day of induction $(\mathrm{pg} / \mathrm{mL})+++$ Number of mature follicles $(>16 \mathrm{~mm}) \quad+++$ Number of oocytes ++

Oocytes quality $\left(1^{\text {st }-2 \text { nd }-3^{\text {rd }}-4^{\text {th }}}\right)++$

Fertilization index $++$

$\mathrm{sO}_{2}(\%), \mathrm{pO}_{2}(\mathrm{mmHg}) \quad+++$

Number of embryos ++

Embryos quality (1 $1^{\text {st }}-2^{\text {nd }}-3^{\text {rd }}-4^{\text {th }}$ class $)$

Embryonic implantation percentage 
With the + sign we meant to indicate a percentage increase between 1 and $10 \%$, with the ++ sign an increase from 11 to $15 \%$, with the +++ sign the increase of more than $16 \%$. It should be noted that the maximum percentage increase was $24 \%$ of implantation with transfer of vitrified embryos. The analysis of the results shows an increase in all parameters, i.e. a better condition of the uterus at the implantation; in fact, we observed a better perfusion of the uterus and a greater growth of the endometrium. The response of the ovary also has been satisfactory; a greater production of hormones and follicles has been observed, but at the same time the number and quality of oocytes has not gone hand-in-hand, even if they provided higher values. The good percentage of embryos implantation is linked to the greater number and quality, but above all to the better conditions of the uterus.

\section{Conclusions}

Our observations show that the oxygen-ozone therapy is certainly an adjuvant therapy in IVF treatments. The feeling is that by selecting the best patients we can obtain even more satisfactory results; in fact, even if not reported in the tables for comparisons, the best results were obtained by comparing in the two groups particularly the various parameters in the most advanced age groups and in cases of sterility with underlying atrophic-inflammatory processes.

For this reason, further studies and observations are underway and procedures are being developed with topical application at the level of the uterus and ovary.

\section{References}

1. Bocci VA. Aspetti scientifici e medici dell'ozono terapia. All'avanguardia. Arch Med Res . 2006; 37: 425-435.

2. Sugita H, Asai T, Hayashi K, et al. Applicazione della disinfezione con ozono per rimuovere Enterococcus seriolicida, Pasteurella piscicida e Vibrio anguillarum dall'acqua di mare. Appl Environ Microbiol . 1992; 58: 4072-4075.

3. Clavo B, Santana-Rodríguez N, Llontop P, et al. L'ozono terapia come adiuvante per il trattamento del cancro: sono necessarie ulteriori ricerche? Evid Based Complement Alternat Med . 2018; 2018: 7.931.849.

4. Karatieieva S, Carne I, Yurkiv O, Semenenko S, Kozlovskaya I. Nuovo metodo di trattamento delle complicanze dei tessuti molli pyoinfiammatori nei pazienti con diabete mellito. Georgian Med News . 2017: 58-60.

5. Gloor M, Lipphardt BA. Studi sull'ozono terapia dell'acne vulgaris. Z Hautkr. 1976; 51: 97-101.

6. Kosheleva IV, Kulikov AG. Efficacia della terapia complessa dei pazienti con eczema con l'uso di vari metodi di ozono ter-

Table 2. The parameters used Group C.

\begin{tabular}{ll} 
Evaluated parameters & Group C \\
$\begin{array}{l}\text { Endometrial size at the time of association } \\
\text { with progestin and transfer }\end{array}$ & ++ \\
$\mathrm{sO}_{2}$ and $\mathrm{pO}_{2}$ values at transfer & +++ \\
\hline Implantation percentage & $24 \%$ \\
\hline
\end{tabular}

apia. Vopr Kurortol Fizioter Lech Fiz Kult . 2001: 40-42.

7. Garber GE, Cameron DW, Hawley-Foss N, Greenway D, Shannon ME. L'uso del sangue trattato con ozono nella terapia dell'infezione da HIV e delle malattie immunitarie: uno studio pilota di sicurezza ed efficacia. AIDS . 1991; 5: 981-984.

8. Carpendale MT, Freeberg J, Griffiss JM. L'ozono allevia la diarrea da AIDS? J Clin Gastroenterol . 1993; 17: 142-145.

9. Hidalgo-Tallón J, Menéndez-Cepero S, Vilchez JS, RodríguezLópez CM, Calandre EP. Ozonoterapia come trattamento aggiuntivo nella gestione della fibromialgia mediante insufflazione rettale: uno studio pilota in aperto. J Altern Complemento Med. 2012; 19: 238-242.

10. Raeissadat SA, Rayegani SM, Forogh B, Hassan Abadi P, Moridnia M, Rahimi Dehgolan S. Ozono intrarticolare o iniezione di acido ialuronico: quale è superiore nei pazienti con osteoartrosi del ginocchio? Uno studio clinico randomizzato di 6 mesi. J Pain Res . 2018; 11: 111-117.

11. Turner CR, Kleeberger SR, Spannhake EW. La preesposizione all'ozono blocca la risposta asmatica tardiva indotta dall'antigene delle vie aeree periferiche del cane. J Toxicol Environ Health . 1989; 28: 363-371.

12. Kucukgul A, Erdogan S, Gonenci R, Ozan G. Effetti benefici dell'ozono non tossico sullo stress e sull'infiammazione indotti da H 2 O 2 . Biochem Cell Biol . 2016; 94: 577- 583.

13. Buyuklu M, Kandemir FM, Set T, et al. Gli effetti benefici della terapia con ozono su stress ossidativo, funzioni cardiache e risultati clinici in pazienti con insufficienza cardiaca hanno ridotto la frazione di eiezione. Cardiovasc Toxicol . 2017; 17 : 426-433.

14. Safwat MH, El-Sawalhi MM, Mausouf MN, Shaheen AA. L'ozono migliora i cambiamenti dello stress ossidativo legati all'età nel fegato e nei reni di ratto: effetti della somministrazione pre e post invecchiamento. Biochimica (Mosc) . 2014; 79: $450-458$.

15. Fitzpatrick E, Olanda OJ, Vanderlelie JJ. Ozonoterapia per il trattamento delle ferite croniche: una revisione sistematica. Int Ferita J. 2018; 15: 633-644.

16. Di Paolo N, Gaggiotti E, Galli F. Ossigenazione e ozonizzazione del sangue extracorporee: implicazioni cliniche e biologiche dell'ozono terapia. Redox Rep . 2005; 10: 121-130.

17. Steinhart H, Schulz S, Mutters R. Valutazione dell'ossigeno ozonizzato in un modello animale sperimentale di osteomielite come ulteriore opzione di trattamento per l'osteomielite cranica. Eur Arch Otorhinolaryngol . 1999; 256: 153-157.

18. He C, Ma X. Ricanalizzazione distale delle tube di Falloppio mediante trattamento con ozono: uno studio clinico su duecento pazienti cinesi con ostruzione tubarica. Int J Clin Exp Med . 2015; 8: 2958-2961.

19. Wei A, Feng H, Jia XM, Tang H, Liao YY, Li BR. L'ozono terapia migliora l'infiammazione e le lesioni endometriali nei ratti con malattia infiammatoria pelvica. Farmacoterapeuta biomedico . 2018; 107: 1418-1425.

20. Nash DM, Paddison J, Davies Morel MCG, Barnea ER. Il fattore preimpianto modula le risposte infiammatorie acute dell'endometrio equino. Vet Med Sci . 2018; 4: 351- 356.

21. Mitchell CM, Haick A, Nkwopara E, et al. Colonizzazione del tratto genitale superiore da parte di specie batteriche vaginali in donne non gravide. Am J Obstet Gynecol . 2015; 212: 611.e611-619.

22. Zobel R, Martinec R, Ivanović D, et al. Somministrazione di ozono intrauterino per migliorare il tasso di fertilità nei bovini simmentali. Vet Arh . 2014; 84: 1-8.

23. Djuricic D, Vince S, Ablondi M, Dobranic T, Samardzija M. Effetto dell'applicazione preventiva dell'ozono intrauterino 
sull'efficienza riproduttiva nelle vacche Holstein. Riproduci Domest Anim . 2012; 47: 87-91.

24. Đuričić D, Valpotić H, Žura Žaja I, Samardžija M. Confronto tra antibiotici intrauterini e uso medico dell'ozono nelle pecore con placenta trattenuta e conseguente assistenza ostetrica. Riproduci Domest Anim . 2016; 51: 538-540.

25. Djuricic D, Valpotic H, Samardzija M. Il trattamento intrauterino della membrana fetale trattenuta nelle capre da latte per ozono: nuova alternativa alla terapia antibiotica. Riproduci Domest Anim . 2015; 50: 236-239.

26. Chandra-D'Mello R, terapia D'Mello R. sull'infertilità femminile. https: // wwwaustinozonecom / wp-content / uploads / Ozone-Therapy-and-Female- InfertilitypdfOzone 2018.

27. Gautam G, Nakao T. Prevalenza dell'urovagina e dei suoi effetti sulla prestazione riproduttiva nelle mucche Holstein. Teriogenologia . 2009; 71: 1451-1461.

28. Zobel R, Tkalčić S, Štoković I, Pipal I, Buić V. Efficacia dell'ozono come nuova opzione di trattamento per l'urovagina nelle vacche da latte. Riproduci Domest Anim . 2012; 47: 293-298.

29. Spinelli C, Piscioneri J, Strambi S. Torsione annessa negli adolescenti: aggiornamento e revisione della letteratura. Curr Opinioni Obstet Gynecol . 2015; 27: 320-325.

30. Aslan MK, Boybeyi Ö, Şenyücel MF, et al. Effetto protettivo dell'applicazione dell'ozono intraperitoneale nelle lesioni sperimentali da ischemia / riperfusione ovarica. J Pediatr Surg . 2012; 47: 1730-1734.

31. Sayar I, Bicer S, Gursul C, Gürbüzel M, Peker K, Işik A. Effetti protettivi dell'acido ellagico e dell'ozono sulle ovaie di ratto con lesione da ischemia / riperfusione. J Obstet Gynaecol Res . 2016; 42: 52-58.

32. Binda MM, Molinas CR, Koninckx PR. Specie reattive di ossigeno e formazione di adesione: implicazioni cliniche nella prevenzione dell'adesione. Hum Reprod . 2003; 18: 2503-2507.

33. Aydogdu I, Ilbey YO, Coban G, Ekin RG, Mirapoglu SL, Cay A, Kiziltan HS, Ekin ZY, Silay MS, Semerci MB. Does Ozone administration have a protective or therapeutic effect against radiotherapy-induced testicular injury? J Cancer Res Ther. 2019 Mar; 15(Supplement) : S76/-S81

34. Seyam O, Smith NL, Reid I, Gandhi J, Jiang W, Khan SA. Clinical utility of ozone therapy for musculoskeletal disorders. Med Gas Res 2018 Sep 25; 8(3) 103-110

35. Di Mauro R, Cantarella G, Bernardini R, Di Rosa M, Barbagalli I, Distefano A, Avola R, Li Volti GThe Biochemical and Pharmacological Properties of aozone: The Smell of Protection in Acute and Chronic Diseases Int J Mol Sci 2019 Feb1; 20(3) pii: E634

36. Rowen Rj. Ozone Therapy as a primary and sole treatment for acute bacterial infection: case report. Med Gas Res 2018 Sep $25 ; 8(3): 121-124$

37. V. Simonetti, M. Franzini, R.V Iaffaoioli, S. Pandolfi, L. Valdenassi, V. Quagliariello. Anti-inflammatory effects of ozone in human melanoma cells and its modulation of tumor microenviroment. International Journal of Advanced Research (IJAR) 6(7) XX-XX ISSN: 2320-5407 - 2018

38. Karaka IR, Ergun G, Ozturk DN. Is Low-level laser therapy and gaseous ozone application effective on osseointegration of immediately loaded implants? Niger J Clin Pract, 2018 Jun;21(6):703-710.
39. Rowen RJ. Remission of aggressive autoimmune disease (dermatomyositis) with removal of infective jaw pathology and ozone therapy: review and case report. Auto Immun Highlights, 2018 Jun 30; 9(1): 7.

40. Bicer S, Gursul C, Sayar I, Akman O, Cakarli S, Aydin M. Role of ozone therapy in Preventing Testicular Damage in an Experimental Cryptorchid Rat Model. Med Sci Monit. 2018 Aug 21; 24:5832-5839.

41. Li X, Michaeloudes C, Zhang Y, Wiegman CH, Adcock IM, Lian Q, Mak JCW, Bhavsar PK, Chung KF. Mesenchymal stem cells alleviate oxidative stress-induced mitochondrial dysfunction in the airways. J Allergy Clin Immunol. 2018 May;141(5):1634-1645.e5.

42. Wu MY, Xing CY, Wang JN, Li Y, Lin XW, Fu ZJ. Therapeutic dosage of ozone inhibits autophagy and apopstosis of nerve roots in a chemically induced radiculoneuritis rat model. Eur Rev Med Pharmacol Sci. 2018 Mar;22(6):1787-1797.

43. Wang L, Chen Z, Liu Y, Du Y, Liu X. Ozone oxidative postconditioning inhibits oxidative stress and apoptosis in renal ischemia and reperfusion injury through inhibition of MAPK signaling pathway. Drug Des Devel Ther. 2018 May 21;12:1293-1301.

44. Đuričic D, Valpotić H, Zura Zaja I, Samardžija M. Comparison of Intrauterine Antibiotics versus Ozone Medical Use in Sheep with Retained Placenta and Following Obstetric Assistance. Reprod Domest Anim. 2016 Aug;51(4):538-40.

45. Yarustovskaya OV, Kulikov AG, Shtro LP. Vopr Kurortol Fizioter Lech Fiz Kult. [Ozonotherapy as an efficient component of the combined treatment of the patients presenting with bacterial vaginosis].

46. Bocci V, Zanardi I, Travagli V., Ozone: a new therapeutic agent in vascular diseases. Am J Cardiovasc Drugs. 2011;11(2):73-82.

47. Re L, Sanchez GM, Mawsouf N. Clinical evidence of ozone interaction with pain mediators. Saudi Med J. 2010 Dec;31(12):1363-7.

48. Alberto PO. Ozone the one and only drug. Acta Neurochir Suppl. 2011;108:143-6.

49. Borrelli E., Mechanism of action of oxygen ozone therapy in the treatment of disc herniation and low back pain. Acta Neurochir Suppl. 2011;108:123-5.

50. Kolesova OE, Vasil'ev IT, Volkhovskaia NB, Mumladze RB, Tkachenko SB, Savina GD., Correction of the antioxidative system during ozone therapy in peritonitis. Vestn Ross Akad Med Nauk. 2010;(5):34-9. Russian.

51. Guanche D, Zamora Z, Hernández F, Mena K, Alonso Y, Roda M, Gonzáles M, Gonzales R. Effect of ozone/oxygen mixture on systemic oxidative stress and organic damage. Toxicol Mech Methods. 2010 Jan;20(1):25-30.

52. Paoloni M, Di Sante L, Cacchio A, Apuzzo D, Marotta S, Razzano M, Franzini M, Santilli V. Intramuscular oxygenozone therapy in the treatment of acute back pain with lumbar disc herniation: a multicenter, randomized, double- blind, clinical trial of active and simulated lumbar paravertebral injection. Spine (Phila Pa 1976). 2009 Jun 1;34(13):1337-44.

53. Bocci V, Luzzi E, Corradeschi F, Paulesu L, Di Stefano A., Studies on the biological effects of ozone: 3. An attempt to define conditions for optimal induction of cytokines. Lymphokine Cytokine Res. 1993 Apr;12(2):121-6. 